\title{
Seroprevalence of major infectious causes of dairy cattle reproductive problems in central Ethiopia
}

\section{Yohannes Equar Messele}

National Agricultural Biotechnology Research Center

Gebrerufael Girmay ( $\nabla$ rufel2000@yahoo.com )

National Agricultural Biotechnology Research Center

\section{Bezina Arega Emeru}

National Agricultural Biotechnology Research Center

Shelema Kelbesa Bora

National Agricultural Biotechnology Research Center

Workitu Firomsa Gudeta

National Agricultural Biotechnology Research Center

Betelhem Seyoum Dersso

National Agricultural Biotechnology Research Center

Desiye Tesfaye Tegegne

National Agricultural Biotechnology Research Center

Beksisa Urge Hurrisa

Ethiopian Institute of Agricultural Research, Holeta Agricultural Research Center

Shimels Tikuye Yalew

National Agricultural Biotechnology Research Center

Gebremeskel Mamu Werid

National Agricultural Biotechnology Research Center

\section{Research Article}

Keywords: Reproductive Failure, Dairy cattle, Serology, Ethiopia

Posted Date: December 17th, 2021

DOI: https://doi.org/10.21203/rs.3.rs-1153341/v1

License: (a) (i) This work is licensed under a Creative Commons Attribution 4.0 International License.

Read Full License 


\section{Abstract \\ Background}

Reproductive problem is one of the main constraints of livestock genetic improvement efforts in tropical countries. The aim of this study was to determine the prevalence of major infectious causes of reproductive problems of dairy cattle in selected dairy farms in central Ethiopia. Overall 86 serum samples were collected from October 2018 to February 2019 from animals with history of reproductive problems. The collected serum was tested for antibody titer against Brucella species, Neospora caninum, Bovine Viral Diarrhea (BVD), Infectious Bovine Rhinotracheitis (IBR) and Q-fever using rose-bengal and enzyme-linked immunosorbent assay (ELISA) tests.

\section{Result}

Among the animals with the history of reproductive disordered; abortion, still birth and repeat breeding cases were found in $61.6 \%, 19.8 \%$ and $18.6 \%$, respectively. The prevalence of IBR, BVD, Neospora caninum and Coxiella brunetti was found to be $79.1 \%, 38.4 \%, 3.5 \%$ and $1.2 \%$, respectively. The combined infection of both BVD and IBR were detected in $21 \%$ of animals. Out of the total animals examined in this study, $95.9 \%$ of Jersey breeds were found seropositive to IBR than Boran-Friesian crosses $(57.7 \%)$. The incidence of BVD was significantly higher in Boran-Friesian crossbred cattle than in Jersey which was found to be $69.3 \%$ and 14.3 , respectively. The prevalence of IBR and BVD was directly proportional with age of the animal and parity.

\section{Conclusion}

Vaccination against IBR and BVD is not practiced in Ethiopia, the rising level of those diseases in dairy sector needs regular surveillance and control program.

\section{Background}

Reproductive performance is one of the desired production traits in dairy farming (1). The reproductive performance of dairy cattle mainly depends on their genetic makeup, health, nutrition, husbandry and environment. In addition to the noninfectious causes of reproductive problems such as genetic deformities, heat stress and toxins; reproductive disorders caused by bacteria, viruses, protozoa, and fungi play an important role in the development of animal reproductive problems (2). Reproductive problems of dairy cattle, due to its detrimental effects on the overall fertility, delayed calving interval, medication costs, decreased milk production and shortening the productive age of potentially productive cattle, result a significant economic loss in the dairy industry (3). Some reports indicate that globally almost half of the abortion and still birth cases are caused by infectious agents 
Globally, infectious causes of reproductive problem have become a serious challenge to the dairy industry. The most commonly involved bacterial diseases are Brucella abortus, Chlamydophila abortus, Coxiella burnetii (4); (5); (6). In addition to bacterial pathogens, viruses such as Bovine Viral Diarrhoea (BVD), Infectous Bovine Rhinotrachitis (IBR) and parasites including Neospora caninum and Trichomonas foetus are most commonly associated with reproductive problems (7). Such infectious causes of reproductive problems reduce the production and productivity potential of dairy animals, limit livestock and livestock products to market access and even some pathogens pose a significant health risk to the public (8).

Although different terms and syndromes such as dystocia, retained fetal membrane (RFM), metritis, embryonic death, abortion, infertility and repeat breeder are used to explain reproductive problems in dairy cattle abortion and infertility are the most significant problems affecting dairy herds. Due to the complex nature of the causative agents, the specific cause of abortion and /or infertility in cattle could not be determined easily by observing simple clinical signs or syndromes (9).

Elsewhere, the underlying causes and distribution of dairy cattle reproductive problems has been studied. In Ethiopia, information on the types of dairy cattle reproductive problems and its extent and distribution is scarce. For improving the productivity of dairy cattle, understanding the overall husbandry and animal health related constraints such as reproductive problems on different production and Temporal conditions are important. Exploring further evidences on the reproductive problems of dairy cattle in Ethiopia will help to design specific and effective disease prevention and control strategies that are customized to the existed situation. Therefore, the present study was aimed to determine the prevalence of major reproductive health problems of dairy cattle in selected part of central Ethiopia.

\section{Methods}

\section{Study Area}

The study was carried from October 2018 to February 2019 in selected farms of central Ethiopia. The area is characterized by a moderately cold climate with a temperature of $6-22^{\circ} \mathrm{C}$. Mean relative humidity of $59 \%$. The annual temperature and rainfall ranges from $18^{\circ} \mathrm{C}$ to $24^{\circ} \mathrm{C}$ and 1000 to $1225 \mathrm{~mm}$, respectively. The area has bimodal rainfall pattern with a short rainy period from March to May and a long rainy season from June to September. The dairy farms have a semi intensive farming system where the animals spent their time frequently by grazing and also an indoor feeding (HARC, 2008).

\section{Study design and sampling}

All dairy cattle, composed of Friesians, Jerseys and their crossbreeds were taken as a target population. The biodata was categorized as: breed (Boran-Fresian cross, Boran-Jersey cross, pure Jersey and pure Boran); age in year $(2-5 ; 6-10 ; 11-15)$ and parity $(0-3 ; 4-6 ; 7-9)$. The associated clinical disorder like abortion, stillbirth, retained fetal membranes, dystocia and prolonged uterine discharge, were also categorized as either present or absent. All the animals selected for the study were maintained under the 
same (semi-intensive) management system. Animals with history of reproductive disorders were purposively considered for investigation of selected infectious causes. From a total 1041 animals, 86 cows were found with the history reproductive problem. Blood samples $(10 \mathrm{ml})$ were collected from the cattle $(n=86)$ with a history of reproductive problems, using sterile needles and plain vacutainer tubes from jugular vein. The collected sera was decanted and transported to Holeta national agricultural biotechnology in ice packs and stored at $-20^{\circ} \mathrm{C}$ until screening. Sample collection and serological analysis were done as per the recommendation by (10). For the purpose of this study, loss of the fetus between 42 and 260 days of gestation was taken as abortion and a calf born dead between 260 days and full term, or died within 24 hours following birth was considered as stillbirth.

\section{Laboratory analysis}

The collected serum was tested for positive antibody titer against Brucella species, Neospora caninum, BVD, IBR, Coxiella burnetii and Chlamydophila abortus using commercial serological kits. Serological analysis was conducted at Holeta Agricultural Biotechnology Research Laboratory. Serum sample was screened using Rose-Bengal Plate Agglutination Test. Serum of $30 \mu \mathrm{l}$ was mixed with an equal volume of antigen on a white tile or enamel plate to produce a zone approximately equal to $2 \mathrm{~cm}$ in diameter. The mixture was rocked gently for four minutes at ambient temperature and then observed for agglutination. Brucella antibody screening was conducted using rosebenagal test (ID.vet, France) followed by the Brucellosis serum indirect multi species test kit. The interpretation was based on S/P\% value where $<110 \%$ was considered negative, $110-120 \%$ doubtful, and $>120 \%$ positive. The detection of IBR was done by IBR indirect (ID.vet, France). The interpretation of IBR exposure was calculated considering the absorbance cut-off value of $<50 \%$ as negative and $>60 \%$ as positive. BVDV exposure status was determined based on a competitive ELISA using the BVD p80 Antibody test (ID.vet, France). Those samples whose percent $S / N<50$ were considered negative, while those with $S / N>50 \%$ were considered positive. The presence of antibodies to $N$. caninum was determined using the $N$. caninum indirect multispecies test kit (ID.vet, France). A serum with absorbance value (S/P) with a cut-off level $<40$ considered as negative, $40-50$ doubtfull and $>50 \%$ was considered to be Neospora positive. The seroprevalence of Coxiella burnetii were determined by monoscreen AbELISA test (Bio-X Diagnostics, Belgium). The coefficient value less than $37 \%$ was considered as negative and those greater than or equal to $37 \%$ were positive. The test protocol and interpretation of all ELISA tests were performed according to the manufacturer's instructions. The test was repeated for doubtful results.

\section{Data analysis}

Data collected from laboratory investigations were entered on Microsoft (Ms) Excel spread sheet for coding, cleaning and validation. The collected data was analyzed using StataSE 15. Descriptive statistics were used to compute frequency and animal level prevalence. To compare prevalence/incidence of different reproductive disorders, $95 \%$ confidence intervals were used. Associations between reproductive health problem and different risk factors were assessed using logistic regression. The strength of association was determined by odds ratio. Statistical significance was determined at $P<0.05$.

\section{Results}




\section{Apparent prevalence at single and mixed levels}

The definition of apparent prevalence is the number of animals testing positive by a diagnostic test divided by the total number of animals in the sample tested. True prevalence is the actual number of diseased animals divided by the number of individuals in the population. Accordingly, the overall apparent prevalence of all the diseases was $30.5 \%$. Infectious Bovine Rhinotracheitis (IBR) was found the highest prevalent disease in the study areas with a prevalence of $79.1 \%$ followed by Bovine Viral Diarrhea (BVD) with a prevalence of $38.4 \%$. On the other hand, there was no even a single case confirmed for bovine brucellosis and Chlamydophila abortus in the study areas.

In this study, Rose bengal was employed to screen the serum samples since the test is well suited for screening of Brucella infections and for analysis of a large number of samples. The samples were further analyzed by specific commercially available ELISA test kit for each target diseases. Indeed, serological surveys indicated that unlike the Brucella disease, other disease using agents including IBR and BVD were found most prevalent and potential predisposing factors for the mentioned reproductive problems (Table 1). The serological analysis held by using Rose bengal and ELISA tess revealed that the breeding stocks were free from brucellosis.

The percentages of cattle that were seropositive for IBR, BVD, N. caninum, and C.brunetti or combinations of these, are described in Table 2. The combined infection of both BVD and IBR were detected in $20.9 \%$ of animals in all the study areas. But, still the single infection caused by IBR was found about 6 times that of the BVD with statistically significant difference.

\section{Associations of reproductive disease disorders with the apparent prevalence}

The three reproductive disorders were the repeated breeding (37.5\%), abortion (29.7\%) and stillbirth (26.5\%). Their overall apparent prevalence did not have statistically significant variation. However, when they are analyzed for each disease independently, statically significant variations were observed. Animals that have abortion cases had about $90 \%$ IBR sero-prevalence which was about 6 times higher than that of repeated breeding which was statistically significant variation. On the contrary, animals that have repeated breeding cases had about $81 \%$ BVD sero-prevalence which was about 14 times higher than that of abortion with statistically significant variation (Table 3).

\section{The effect of breed on reproductive disorders}

The overall apparent prevalence of the reproductive diseases in all the study areas did not have statistically significant variation across breeds (H.F: $34.6 \%$; Jersey: $28.1 \%$; Boran: $33.3 \%$ and Boran cross Jersey: $25.0 \%$ with $X^{2}: 1.62$ and p: 0.6542). However, breed was found to have significant effect within the reproductive diseases. Out of the total 86 animals examined in this study, Jersey (95.9\%) breed was found about 23 times higher seropositive to IBR than Boran breeds (44.4\%) with statistically significant difference. On the other hand, Boran breeds were found to be 3 times more susceptible to BVD than the cross H.F (Table 4). 


\section{The effect of age on different diseases}

The apparent prevalence of IBR (92.3) and BVD (53.8\%) was found to be higher in the ages with 11 years and above. However, the effect of age on the apparent prevalence of these diseases did not have statistically significant difference (Table 5).

\section{The correlation of parity with target diseases}

The apparent prevalence of the different reproductive diseases had variations across the three categories of parities. However, there was no statistically significant difference across the different parities (Table 6).

\section{Discussion}

This study reported some of the major reproductive problems of the dairy cattle kept under semi-intensive production system in the central highlands of Ethiopia. The dairy farm follows semi-intensive management where animals depend for feed on open grazing for green fodder and on barn concentrate supplementation and water provision. In this study, among the animals with history of reproductive disorders like repeat breeding, abortion and still birth cases were found in $37.5 \%, 29.7 \%$ and $26.5 \%$, respectively. These results were similar to previous findings from Sudan, which indicated reproductive problem of dairy cattle as the main bottlenecks of smallholder dairy production (11). Abortion in dairy cattle, in addition to its economic loss, poses a potential health risk to the public.

Due to its improved specificity and sensitivity, ELISA test was used to detect antibodies of different pathogens from dairy cows in the current study (12). For IBR, BVD, N. caninum and C. brunetti, seropositivities of $79.1 \%, 38.4 \%, 3.5 \%$ and $1.2 \%$ were found, respectively. This indicates the alarmingly high prevalence of IBR and BVD diseases in the dairy cattle of the study areas. Since there is no any history of vaccination for these pathogens in the study areas, detection of antibodies from tested cows implies that the animals were exposed to IBR and BVD at some point in time (13).

Intensive management of dairy cows favors viral spread and raises the chances that healthy animals can come into contact with infected animals (14). Depending on the history of reproductive problem of the herd, IBR seropositive was found to be $90.6 \%$ for abortion cases, $62.5 \%$ for repeat breeding cases and $58.8 \%$ for still birth cases. Similar finding were reported from India with $79.69 \%, 76.32 \%, 76.09 \%$ and $58.33 \%$ of abortion, repeat breeding, retention of placenta and metritis cases for sero-posetive IBR infection, respectively (15). Some reports showed that from the viral causes of abortion in dairy cattle, IBR is the most frequently diagnosed pathogen. (16) reported a sero-prevalence of IBR that ranges from $19.5-86 \%$. Similarly, in this study, BVD was also found to be $81.2 \%, 22.6 \%$ and $47.1 \%$ in repeat breeding, abortion and still birth cases, respectively. The higher prevalence of IBR might be attributed to use of contaminated semen, poor husbandry practices and introduction of unscreened new cows/bulls to the herds. In Ethiopia, the available evidences on the impact and features of IBR and BVD on dairy cattle are 
not strong enough. And hence, appropriate control and prevention measures of these diseases including vaccination and biosecurity practices haven't been practiced in the country.

In addition to BVD and IBR, $N$. caninum, which is protozoan parasite widely recognized as a cause of abortions in dairy cattle has also been diagnosed in the current study with a prevalence of $3.5 \%$. A previous study in the central and southern Ethiopia was found a strong association of N. caninum seropositivity and abortion in cattle (17). A similar finding was also reported from New Zealand (18). Though comprehensive evidence on the disease burden of N.caninum in Ethiopian dairy cattle is missing, the current study showed that N.caninum shouldn't be ignored.

In the current study, the sero-prevalence of $C$. brunetti was $1.2 \%$. Since all the $C$. brunetti positive cows were with a history of repeat breeding, no association was found between abortion and $C$. brunetti. The observed prevalence was similar with the finding reported from Algeria with the prevalence of $1.67 \%$ (19). However, compared to the current study, higher sero-prevalence of $12.3 \%$ in dairy cows was reported from Spain (20).

In this study, more than half (54.5\%) percent were found sero-positive for IBR. This was about 6 times the apparent prevalence of IBD. About 21 percent of the tested animals areas were sero-positive for both IBR and BVD. Similarly, (9) from South Africa reported a seroprevalence of $41.37 \%$ of the animals for combined infection of both BVD and IBR. The genetic makeup of animals had a significant effect on abortion; repeat breeding, still birth, retention of placenta, and endometritis. In this study, four different genetic groups such as Fresian-Boran cross; Pure Jersey, Pure Boran and Jersey-Boran crossbred cattle were selected. As a result, a higher prevalence of IBR was found in Jersey $(95.9 \%)$ and Boran Jersey cross (100\%). In contrast, higher prevalence of BVD was found in pure Boran and in HFB with $88.9 \%$ and $69.3 \%$, respectively. Compared to the Boran, which are locally adapted cattle breeds, HF and Jersey breeds are exotic breeds imported to Ethiopia for their higher milk production. The higher prevalence of reproductive problems in both HF and Jersey cross might be due to the animals' less adaptability to tropical environment and suboptimal husbandry practices (21).

Parity had considerable effect on the occurrence of various reproductive infections. As the parity increases the probability of getting infection also increased. Maximum sero-positivity of IBR $(100 \%)$ and BVD $(100 \%)$ were found in animals 7 and above years of age (Table 7$)$ which is similar with (15) who indicated that animals more than 7 years of age are more prone to IBR virus infection than younger animals. The possible reason why older animals are more prone to infection might be production stress. Higher age group might lead to activation of latent infection and there may be more chances of such animals get exposed to infection. In conclusion, the previously uncommon cattle diseases such as BVD and IBR were found in a higher prevalence. Since there are no vaccinations against BVD and IBR in Ethiopia, the higher prevalence of these diseases in all age group may indicate natural circulation of viruses in the population. But this doesn't necessarily justify the clinical and epidemiological importance of theses disease in Ethiopia. Thus, for designing effective control and prevention programs of these diseases, thorough investigation on the epidemiology of the diseases supported by virus isolation and 
demonstration of active infection should be done across different dairy production systems and agroecological zones of the country. This study also suggests the need of an intensive control and surveillance programs for reducing BVD and IBR infection rates in dairy cattle in Ethiopia.

\section{Conclusion}

The present study has shown as abortion took more than $60 \%$ of the reproductive disorders among the different study areas. Among the causative agents for the reproductive disorders, IBR took the major contribution followed by BVD. Currently, there is no vaccination scheme for these very important disease here in Ethiopia. As we have got from none published information (personal communication with farm owners) IBR is forcing to close dairy farms after they confirms as the disease is IBR. This needs urgent vaccination scheme to be introduced to the country.

\section{Study Limitation}

- The study need to address vast areas to give a national picture on the current findings so that the data would be strong enough for the government to take immediate action.

- There need to use molecular study so as to identify the active causative agents currently circulating in the country.

\section{Declarations}

\section{Acknowledgements}

I greatly appreciate the contribution made by the Ethiopian National Agricultural Biotechnology Research Center in funding this project and the staff of the Animal Biotechnology Laboratory, for assisting during the bench work which has led to the success of this work.

\section{Authors' contributions}

The research idea and study design were developed by YEM and GMW. Sample collection were done by YEM, GGA, BAE, SKB, WFG, BSD, DTT, STY and BUH. YEM supervised the study. YEM and GGA provided valuable information on data analysis and manuscript writing. All authors read and approved the final manuscript.

Funding information: This study received financial support from the Ethiopian Institute of Agricultural Research.

Data availability: the datasets generated during and/or analyzed during the current study are available from the corresponding author on reasonable request.

Ethics approval and consent to participate 
Ethical approval to conduct the study was obtained from the Ethiopian Institute of Agricultural Research. Permissions to conduct field collection of blood samples were obtained from the district, area leaders and farm owners.

Statement of animal right: The manuscript does not contain clinical studies or patient data.

Conflict of interest: The authors declare that they have no conflict of interest.

Consent: Not applicable

\section{References}

1. Ansari-lari M, Kafi M. Reproductive performance of Holstein dairy cows in Iran Reproductive performance of Holstein dairy cows in Iran. 2010;(May 2018).

2. Clothier K, Anderson M. California Animal Health \& Food Safety Lab System, School of Veterinary Medicine and. Theriogenology [Internet]. 2015; Available from:

http://dx.doi.org/10.1016/j.theriogenology.2015.11.001

3. Lobago F. Reproductive and lactation performnace of daíry cattle in the Oromia Central Highlands of Ethiopia Reproductive and Lactation Performance of Dairy Cattle in the Oromia Central Highlands of Ethiopia with Special Emphasis on Pregnancy Period Swedish University of Agricultural Sciences. 2014.

4. Olsen SC, Palmer M V. Veterinary Pathology Online. 2014;(June).

5. Kaltenboeck B, Hehnen H, Vaglenov A. Bovine Chlamydophila spp. Infection : Do We Underestimate the Impact on Fertility ? 2005;29:1-15.

6. Agerholm JS. Coxiella burnetii associated reproductive disorders in domestic animals-a critical review. 2013;1-11.

7. Felleisen RSJ, Lambelet N, Bachmann P, Nicolet J, Gottstein B, Mu N. Detection of Tritrichomonas foetus by PCR and DNA Enzyme Immunoassay Based on rRNA Gene Unit Sequences. 1998;36(2):513-9.

8. Anderson ML. Infectious causes of bovine abortion during mid- to late-gestation. 2007;68:474-86.

9. Njiro SM, Kidanemariam AG, Tsotetsi AM, Katsande TC, Mnisi M, Lubisi BA. A study of some infectious causes of reproductive disorders in cattle owned by resource-poor farmers in Gauteng Province, South Africa. 2011;82:213-8.

10. Daw MA. MEDICAL MICROBIOLOGY LABORATORY MANUAL Second Edition 2009 MEDICAL MICROBIOLOGY Second Edition Department of Microbiology and Immunology Faculty of Medicine, Alfateh University Triboli, Libya. 2016;(November). 
11. Elhassan AM, Fadol MA, Mohamed A, Elfahal A, Rahim A, Elhassan AM, et al. A cross sectional study on reproductive health disorders in dairy cattle in Sudan A cross sectional study on reproductive health disorders in dairy cattle in Sudan. 2018;(January 2015).

12. El-mahallawy HS, Kelly P, Zhang J, Yang Y, Zhang H, Wei L, et al. High seroprevalence of Coxiella burnetii in dairy cattle in China. 2015;10-3.

13. Kampa J, Chanlun A, Aiumlamai S, Alenius S. BVDV and BHV-1 Infections in Dairy Herds in Northern and Northeastern Thailand. 2004;45(3):181-92.

14. Chandranaik BM, Rathnamma D, Patil SS, Ranganatha S, Kovi RC, Akhila DS, et al. Epidemiology of bovine herpes virus-1 under different housing practices in cattle breeding stations. 2014;84(February):103-7.

15. Kathiriya J, Sindhi S, Mathapati B, Bhedi K. Seroprevalence of Infectious Bovine Rhinotracheitis ( BHV1 ) in Dairy Animals with Reproductive Disorders in Saurashtra of Gujarat, India. 2018;7(03):1371-6.

16. Hovingh E, Veterinarian E, Tech V. Common Causes of Abortions Abortions in Dairy Cattle - I. 2009;

17. Dubey JP, Schares G. Epidemiology and Control of Neosporosis and Neospora caninum. 2007;20(2):323-67.

18. Sanhueza JM, Heuer C, West D. Contribution of Leptospira, Neospora caninum and bovine viral diarrhea virus to fetal loss of beef cattle in New Zealand. Prev Vet Med [Internet]. 2013;112(1-2):90-8. Available from: http://dx.doi.org/10.1016/j.prevetmed.2013.07.009

19. Derdour S, Hafsi F, Azzag N, Tennah S, Laamari A, Ghalmi F. Prevalence of the main infectious causes of abortion in dairy cattle in Algeria. 2017;337-43.

20. Astobiza I, Piñero A, Barandika JF, Hurtado A. Estimation of Coxiella burnetii prevalence in dairy cattle in intensive systems by serological and molecular analyses of bulk-tank milk samples. J Dairy Sci [Internet]. 2012;95(4):1632-8. Available from: http://dx.doi.org/10.3168/jds.2011-4721

21. Khan MH, Manoj K, Pramod S. Reproductive disorders in dairy cattle under semi-intensive system of rearing in North-Eastern India. 2016;9:512-8.

\section{Tables}

Table 1: Prevalence of reproductive infections in dairy cattle 


\begin{tabular}{|lllllll|}
\hline $\begin{array}{l}\text { Type of } \\
\text { disease }\end{array}$ & $\begin{array}{l}\text { Number of } \\
\text { animals } \\
\text { examined }\end{array}$ & $\begin{array}{l}\text { Number of } \\
\text { positives }\end{array}$ & $\begin{array}{l}\text { Apparent } \\
\text { prevalence }\end{array}$ & $\begin{array}{l}\text { 95\% Cl for } \\
\text { Apparent } \\
\text { prevalence }\end{array}$ & OR & $\begin{array}{c}95 \% \mathrm{Cl} \\
\text { for OR }\end{array}$ \\
\hline $\begin{array}{l}\text { Bovine } \\
\text { brucellosis }\end{array}$ & 86 & 0 & 0.0 & - & - & \\
\hline IBR & 86 & 68 & 79.1 & $69.2-86.4$ & 321.1 & $\begin{array}{l}41.8 \\
2466.5\end{array}$ \\
\hline BVD & 86 & 33 & 38.4 & $15.8-67.3$ & 52.9 & $7.0-$ \\
\hline $\begin{array}{l}\text { N. } \\
\text { caninum }\end{array}$ & 86 & 3 & 3.5 & $0.01-17.7$ & 3.1 & $0.3-$ \\
\hline C. brunetti & 86 & 1 & 1.2 & $0.1-13.2$ & 1 & 30.1 \\
\hline C. abortus & 86 & 1 & 0.0 & - & - & \\
\hline Total & 344 & 0 & 30.5 & $25.9-35.6$ & & \\
\hline
\end{tabular}

$X^{2}=183.6, p<0.05 ;$ OR- Odds Ratio; $\mathrm{Cl}$ - Confidence Interval

Table 2. The number of single and mixed infections

\begin{tabular}{|c|c|c|c|c|c|c|c|}
\hline $\begin{array}{l}\text { Type of } \\
\text { disease }\end{array}$ & $\begin{array}{l}\text { Number of } \\
\text { animals } \\
\text { examined }\end{array}$ & $\begin{array}{l}\text { Number } \\
\text { of } \\
\text { positives }\end{array}$ & $\begin{array}{l}\text { Apparent } \\
\text { prevalence }\end{array}$ & $\begin{array}{l}95 \% \mathrm{Cl} \text { for } \\
\text { Apparent } \\
\text { prevalence }\end{array}$ & OR & $x^{2}$ & $\begin{array}{l}\mathrm{p}- \\
\text { Value }\end{array}$ \\
\hline BVD & 86 & 14 & 16.3 & $9.9-25.6$ & 1 & \multirow[t]{7}{*}{131.27} & \multirow[t]{6}{*}{$<0.05$} \\
\hline IBR & 86 & 47 & 54.7 & $25.0-81.3$ & 6.2 & & \\
\hline N. caninum & 86 & 1 & 1.2 & $0.1-14.0$ & 0.06 & & \\
\hline $\begin{array}{l}\text { BVD and } \\
\text { IBR }\end{array}$ & 86 & 18 & 20.9 & $6.4-50.4$ & 1.4 & & \\
\hline $\begin{array}{l}\text { N. caninum } \\
\text { and IBR }\end{array}$ & 86 & 2 & 2.3 & $0.3-16.1$ & 0.12 & & \\
\hline $\begin{array}{l}\text { BVD, IBR } \\
\text { and } \\
\text { C. brunetti }\end{array}$ & 86 & 1 & 1.2 & $0.1-14.0$ & 0.06 & & \\
\hline Total & 516 & 83 & 16.1 & $13.2-19.5$ & & & \\
\hline
\end{tabular}

OR- Odds Ratio; Cl- Confidence Interval

Table 3. The most common type of reproductive disorder in Holeta and Adaberga dairy farms

A. Prevalence - Apparent prevalence; OR- Odds Ratio; $\mathrm{Cl}$ - Confidence Interval 


\begin{tabular}{|c|c|c|c|c|c|c|c|}
\hline Diseases & Disorder & $\begin{array}{l}\text { Total animal } \\
\text { examined }\end{array}$ & $\begin{array}{l}\text { Apparent } \\
\text { prevalence }\end{array}$ & $\begin{array}{l}95 \% \mathrm{Cl} \text { of } \mathrm{A} \text {. } \\
\text { prevalence }\end{array}$ & OR & $x^{2}$ & $\begin{array}{l}\mathrm{p}- \\
\text { value }\end{array}$ \\
\hline \multirow[t]{4}{*}{ IBR } & $\begin{array}{l}\text { R. } \\
\text { breeding }\end{array}$ & 16 & 62.5 & $37.7-82.1$ & 1 & \multirow[t]{4}{*}{10.92} & \multirow[t]{4}{*}{0.0043} \\
\hline & Abortion & 53 & 90.6 & $47.0-99.0$ & 5.8 & & \\
\hline & $\begin{array}{l}\text { Still } \\
\text { birth }\end{array}$ & 17 & 58.8 & $11.4-99.1$ & 0.86 & & \\
\hline & Total & 86 & 79.1 & $69.2-86.4$ & & & \\
\hline \multirow[t]{4}{*}{ BVD } & $\begin{array}{l}\text { R. } \\
\text { breeding }\end{array}$ & 16 & 81.3 & $55.3-93.8$ & 1 & \multirow[t]{4}{*}{18.88} & \multirow[t]{3}{*}{0.001} \\
\hline & Abortion & 53 & 22.6 & $2.0-80.8$ & 0.07 & & \\
\hline & $\begin{array}{l}\text { Still } \\
\text { birth }\end{array}$ & 17 & 47.1 & $5.0-93.8$ & 0.21 & & \\
\hline & Total & 86 & 38.4 & 28.7-49. & & & \\
\hline \multirow[t]{4}{*}{$\begin{array}{l}\mathrm{N} \text {. } \\
\text { caninum }\end{array}$} & $\begin{array}{l}\mathrm{R} . \\
\text { breeding }\end{array}$ & 16 & 0.0 & - & - & \multirow[t]{4}{*}{-} & \multirow[t]{3}{*}{-} \\
\hline & Abortion & 53 & 5.7 & $1.8-16.1$ & - & & \\
\hline & $\begin{array}{l}\text { Still } \\
\text { birth }\end{array}$ & 17 & 0.0 & & - & & \\
\hline & Total & 86 & 3.5 & $1.1-10.3$ & & & \\
\hline \multirow[t]{4}{*}{$\begin{array}{l}\text { C. } \\
\text { burnetti }\end{array}$} & $\begin{array}{l}\mathrm{R} \text {. } \\
\text { breeding }\end{array}$ & 16 & 6.3 & $0.9-33.5$ & - & \multirow[t]{3}{*}{-} & \multirow[t]{3}{*}{-} \\
\hline & Abortion & 53 & 0.0 & & - & & \\
\hline & $\begin{array}{l}\text { Still } \\
\text { birth }\end{array}$ & 17 & 0.0 & & - & & \\
\hline & Total & 86 & 1.2 & $0.2-7.8$ & & & \\
\hline \multicolumn{2}{|c|}{ Grand Total } & 344 & 30.5 & $25.9-35.6$ & & & \\
\hline
\end{tabular}

Table 4. The effect of breed on the four common reproductive disorder diseases

HFB= Holestain fresian-Boran cross; BoJ= Boran Jersey cross

Table 5. Major reproductive diseases identified in different age groups

A. prevalence- Apparent prevalence; OR- Odds Ratio; Cl- Confidence Interval

Table 6. The effect of parity on the apparent prevalence of different reproductive diseases 


\begin{tabular}{|c|c|c|c|c|c|c|c|}
\hline Diseases & Breed & $\begin{array}{l}\text { Total animal } \\
\text { examined }\end{array}$ & $\begin{array}{l}\text { Apparent } \\
\text { prevalence }\end{array}$ & $\begin{array}{l}95 \% \mathrm{Cl} \text { of } \mathrm{A} . \\
\text { prevalence }\end{array}$ & OR & $x^{2}$ & $\begin{array}{l}\mathrm{p}- \\
\text { value }\end{array}$ \\
\hline \multirow[t]{5}{*}{ IBR } & H.F & 26 & $57.7 a$ & $38.5-74.8$ & 1.7 & \multirow[t]{5}{*}{22.79} & \multirow[t]{3}{*}{$<0.05$} \\
\hline & Jersey & 49 & $95.9 b$ & $68.2-99.6$ & 29.4 & & \\
\hline & Boran & 9 & $44.4 b$ & $7.4-88.9$ & 1 & & \\
\hline & JoB & 2 & 100.0 & - & - & & \\
\hline & Total & 86 & 79.1 & $69.2-86.4$ & & & \\
\hline \multirow[t]{5}{*}{ BVD } & H.F & 26 & $69.2 \mathrm{a}$ & $49.5-83.8$ & 0.3 & \multirow[t]{3}{*}{33.99} & \multirow[t]{3}{*}{$<0.05$} \\
\hline & Jersey & 49 & $14.3 \mathrm{~b}$ & $2.2-54.9$ & 0.02 & & \\
\hline & Boran & 9 & 88.9 a & $27.0-99.4$ & 1 & & \\
\hline & JoB & 2 & 0.0 & - & - & & \\
\hline & Total & 86 & 38.4 & $28.7-49.0$ & & & \\
\hline \multirow[t]{5}{*}{ N.caninum } & H.F & 26 & 7.7 & $1.9-26.1$ & 4 & \multirow[t]{3}{*}{1.33} & \multirow[t]{3}{*}{0.2494} \\
\hline & Jersey & 49 & 2.0 & $0.04-50.5$ & 1 & & \\
\hline & Boran & 9 & 0.0 & - & - & & \\
\hline & JoB & 2 & 0.0 & - & - & & \\
\hline & Total & 86 & 3.5 & $1.1-10.3$ & & & \\
\hline \multirow[t]{5}{*}{ C.burnetti } & H.F & 26 & 3.8 & $0.5-27.8$ & - & \multirow[t]{3}{*}{-} & \multirow[t]{3}{*}{-} \\
\hline & Jersey & 49 & 0.0 & - & - & & \\
\hline & Boran & 9 & 0.0 & - & - & & \\
\hline & JoB & 2 & 0.0 & - & - & & \\
\hline & Total & 86 & 1.2 & $0.2-7.8$ & & & \\
\hline Grand Total & & 344 & 30.5 & $25.9-35.6$ & & & \\
\hline
\end{tabular}

A. prevalence- Apparent prevalence; OR- Odds Ratio; $\mathrm{Cl}$ - Confidence Interval

Figures 


\begin{tabular}{|c|c|c|c|c|c|c|c|}
\hline Diseases & Age & $\begin{array}{l}\text { Total animal } \\
\text { examined }\end{array}$ & $\begin{array}{l}\text { Apparent } \\
\text { prevalence }\end{array}$ & $\begin{array}{l}95 \% \mathrm{Cl} \text { of } \mathrm{A} . \\
\text { prevalence }\end{array}$ & OR & $x^{2}$ & $\begin{array}{l}\mathrm{p}- \\
\text { value }\end{array}$ \\
\hline \multirow[t]{4}{*}{ IBR } & $\begin{array}{l}\text { Less } \\
\text { than } 5\end{array}$ & 43 & 81.4 & $67.0-90.4$ & 1 & \multirow[t]{4}{*}{3.22} & \multirow[t]{4}{*}{0.1998} \\
\hline & $5-11$ & 30 & 70.0 & $26.6-93.8$ & 0.5 & & \\
\hline & $\begin{array}{l}11 \text { and } \\
\text { above }\end{array}$ & 13 & 92.3 & $38.6-99.6$ & 2.7 & & \\
\hline & Total & 86 & 79.1 & $69.2-86.4$ & & & \\
\hline \multirow[t]{4}{*}{ BVD } & $\begin{array}{l}\text { Less } \\
\text { than } 5\end{array}$ & 43 & 27.9 & $16.6-43.0$ & 1 & \multirow[t]{4}{*}{4.21} & \multirow[t]{3}{*}{0.1219} \\
\hline & $5-11$ & 30 & 46.7 & $14.4-81.9$ & 2.3 & & \\
\hline & $\begin{array}{l}11 \text { and } \\
\text { above }\end{array}$ & 13 & 53.8 & $14.3-89.1$ & 3.0 & & \\
\hline & Total & 86 & 38.4 & $28.7-49.0$ & & & \\
\hline \multirow[t]{4}{*}{ N.caninum } & $\begin{array}{l}\text { Less } \\
\text { than } 5\end{array}$ & 43 & 7.0 & 2.3-19.5 & & \multirow[t]{4}{*}{-} & \multirow[t]{3}{*}{-} \\
\hline & $5-11$ & 30 & 0.0 & - & & & \\
\hline & $\begin{array}{l}11 \text { and } \\
\text { above }\end{array}$ & 13 & 0.0 & - & & & \\
\hline & Total & 86 & 3.5 & $1.1-10.3$ & & & \\
\hline \multirow[t]{4}{*}{ C.burnetti } & $\begin{array}{l}\text { Less } \\
\text { than } 5\end{array}$ & 43 & 0.0 & - & & \multirow[t]{3}{*}{-} & \multirow[t]{3}{*}{-} \\
\hline & $5-11$ & 30 & 3.3 & $0.5-20.2$ & & & \\
\hline & $\begin{array}{l}11 \text { and } \\
\text { above }\end{array}$ & 13 & 0.0 & - & & & \\
\hline & Total & 86 & 1.2 & $0.2-7.8$ & & & \\
\hline Grand Total & & 344 & 30.5 & $25.9-35.6$ & & & \\
\hline
\end{tabular}




\begin{tabular}{|c|c|c|c|c|c|c|c|}
\hline Diseases & Parity & $\begin{array}{l}\text { Total animal } \\
\text { examined }\end{array}$ & $\begin{array}{l}\text { Apparent } \\
\text { prevalence }\end{array}$ & $\begin{array}{l}95 \% \mathrm{Cl} \text { of } \mathrm{A} . \\
\text { prevalence }\end{array}$ & OR & $x^{2}$ & $\begin{array}{l}\mathrm{p}- \\
\text { value }\end{array}$ \\
\hline \multirow[t]{4}{*}{ IBR } & $\begin{array}{l}\text { Less } \\
\text { than } 3\end{array}$ & 67 & 80.6 & $69.4-88.4$ & 1 & \multirow[t]{4}{*}{1} & \multirow[t]{3}{*}{0.3175} \\
\hline & $3-7$ & 16 & 68.8 & $26.2-93.2$ & 0.5 & & \\
\hline & $\begin{array}{l}7 \text { and } \\
\text { above }\end{array}$ & 3 & 100.0 & - & - & & \\
\hline & Total & 86 & 79.1 & $69.2-86.4$ & & & \\
\hline \multirow[t]{4}{*}{ BVD } & $\begin{array}{l}\text { Less } \\
\text { than } 3\end{array}$ & 67 & 31.3 & $21.4-43.3$ & 1 & \multirow[t]{3}{*}{3.35} & \multirow[t]{3}{*}{0.0672} \\
\hline & $3-7$ & 16 & 56.3 & $20.1-86.8$ & 2.8 & & \\
\hline & $\begin{array}{l}7 \text { and } \\
\text { above }\end{array}$ & 3 & 100.0 & - & - & & \\
\hline & Total & 86 & 38.4 & $28.7-49.0$ & & & \\
\hline \multirow[t]{4}{*}{ N.caninum } & $\begin{array}{l}\text { Less } \\
\text { than } 3\end{array}$ & 67 & 4.5 & $1.5-13.0$ & - & \multirow[t]{3}{*}{-} & \multirow[t]{3}{*}{-} \\
\hline & $3-7$ & 16 & 0.0 & - & & & \\
\hline & $\begin{array}{l}7 \text { and } \\
\text { above }\end{array}$ & 3 & 0.0 & - & & & \\
\hline & Total & 86 & 3.5 & $1.1-10.3$ & & & \\
\hline \multirow[t]{4}{*}{ C.burnetti } & $\begin{array}{l}\text { Less } \\
\text { than } 3\end{array}$ & 67 & 1.5 & $0.2-9.8$ & - & \multirow[t]{3}{*}{-} & \multirow[t]{3}{*}{-} \\
\hline & $3-7$ & 16 & 0.0 & - & & & \\
\hline & $\begin{array}{l}7 \text { and } \\
\text { above }\end{array}$ & 3 & 0.0 & - & & & \\
\hline & Total & 86 & 1.2 & $0.2-7.8$ & & & \\
\hline Grand Total & & 344 & 30.5 & $25.9-35.6$ & & & \\
\hline
\end{tabular}




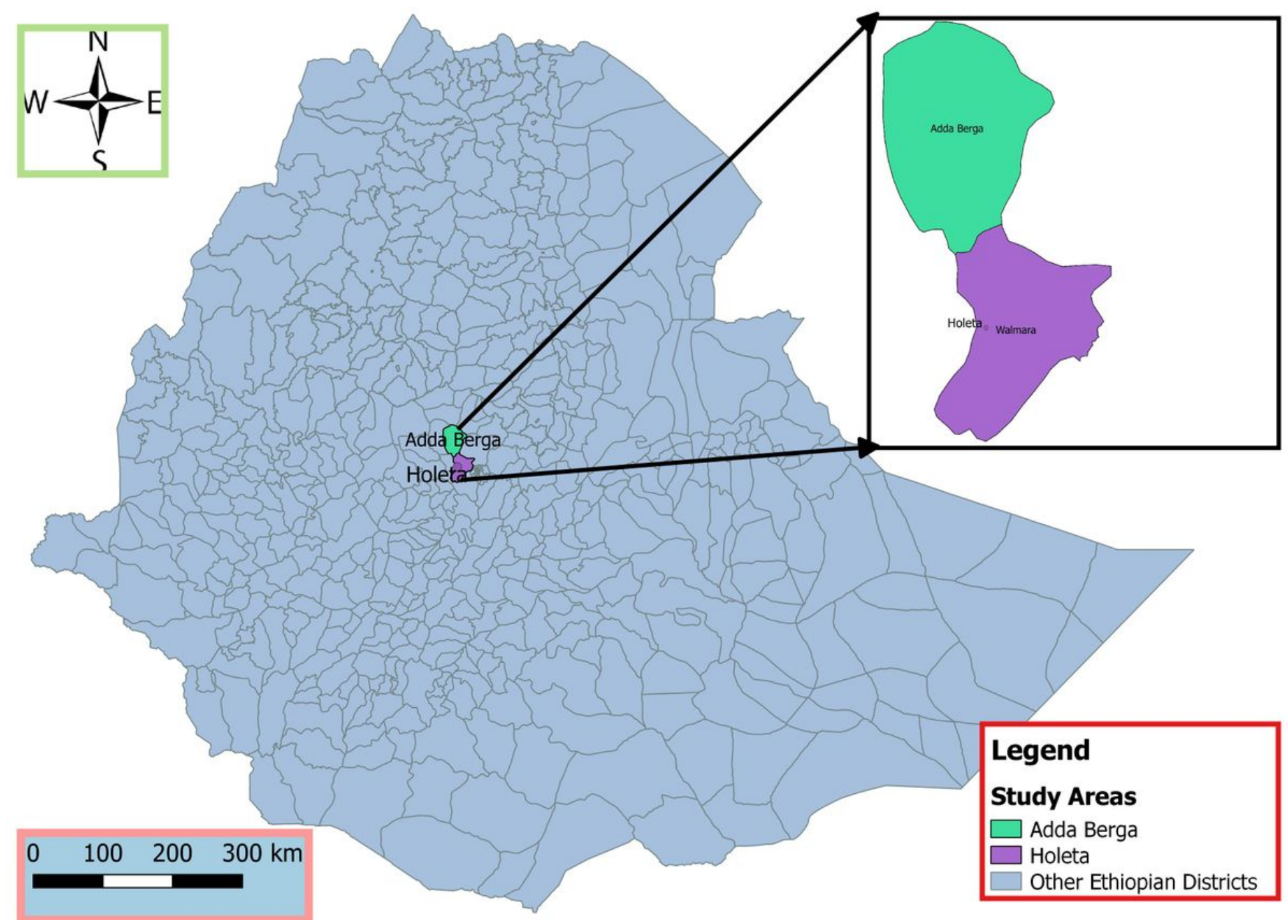

Figure 1

Study areas 


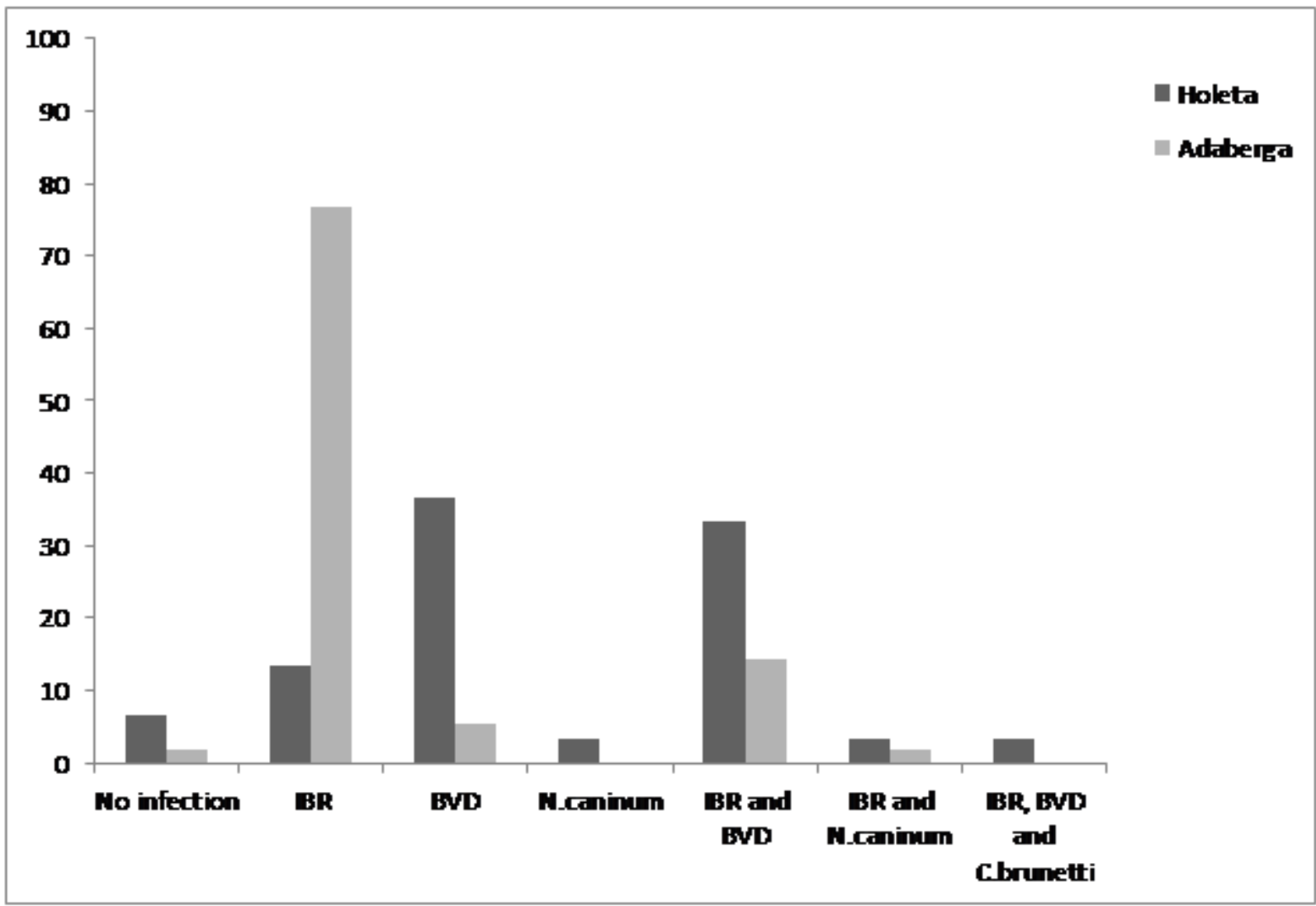

Figure 2

The occurrence of single and mixed infection by different disease in Holeta and Adaberga dairy farms 